\title{
The Policy Analysis of Government Indonesian for Regulation in Media
}

\author{
Taufiqurokhman $^{1}$ and Evi Satispi ${ }^{2}$ \\ Faculty of Social and Political Sciences, Universitas Prof. Dr. Moestopo (Beragama) ${ }^{1}$, Faculty of \\ Social and Political Sciences, Universitas Muhammadiyah Jakarta ${ }^{2}$
}

Keyword: Policy Analysis, Government Regulation on Indonesian Media.

\begin{abstract}
The article writing outlines three important aspects of government regulatory policy analysis of the Indonesian media, namely the identification of law enforcement that needs improvement; background and mechanism of policy making; the power relationships among stakeholders that affect the rights of citizens. The goal is expected to contribute positively to the complexity of media issues in Indonesia and to empower civil society. The location of the study is limited to the existing media in Indonesia using a descriptive research approach with qualitative methodology. The framework of thought of writing takes some of the elements of research, is defining the policy of the practical side and Mutatis Mutandis (important changes made), giving a broad view of policy rather than special decisions, but rather small than general social movements. The results of research with major approaches in research and media analysis are often reduced and fail to recognize the natural characteristics of mass media as the public sphere and the complexity behind the performance of mass media so that it needs to be improved.
\end{abstract}

\section{Introduction}

A number of literatures suggest the importance of the role of any public domain policy (Parsons, 1995). Nevertheless, the importance of policy in analyzing media development, policy aspects often do not appear at all (as recently put forward in the Balabanova study, 2010). In theory, discourse on media development is often released from policy analysis (Coyne and Leeson, 2009). It has a theoretical foundation, arguing that at an empirical level, the policies and developments of the mass media can not be separated; at least in the context of the Indonesian state.

By comparison, before 1998, there were about 279 print media and only five private television stations. Less than a decade later, the number of private television stations doubled (excluding about 20 local television stations) and the number of print media tripled (BPS, 2011). Likewise with radio stations, the increase is not only in terms of numbers, but they are also given more space to create and create content, especially news, after years of being forced to continue broadcasting a government radio station (RRI).

Technological advances and Internet innovations and their usage mark the development of the media industry in Indonesia. The Internet has ceased to be 
considered an alternative medium since the 1998 Reformation, but has been accepted as another form of mass media that journalists and other community members can explore (Laksmi and Haryanto, 2007).

\section{Table 1.}

Overview of Mass Media Changes 2005

(Laksmi dan Haryanto, 2007:53)

\begin{tabular}{|c|c|c|c|}
\hline Media type & $\begin{array}{l}\text { Total Number } \\
\text { Until } 1998\end{array}$ & $\begin{array}{l}\text { Total Number } \\
\text { On } 2005\end{array}$ & Note \\
\hline Media Cetak & 279 & $\begin{array}{l}\text { Expected } \\
600\end{array}$ & $\begin{array}{l}\text { Shaded by longstanding associations, } \\
\text { SPS (Serikat Pekerja Suratkarar) }\end{array}$ \\
\hline Television & & & $\begin{array}{l}\text { Private television stations set up associations } \\
\text { Nem ATVSI (Asosiasion Television Private }\end{array}$ \\
\hline Private National & 5 & 10 & Indonesia) \\
\hline Radio Station & Unknown & 831 & $\begin{array}{l}\text { Shaded by longstanding associations, } \\
\text { PRSSNI (Private Radio Broadcast Association } \\
\text { National Indonesia) }\end{array}$ \\
\hline \multirow[t]{2}{*}{ Media Type } & $\begin{array}{l}\text { Total Number } \\
\text { Until } 1998\end{array}$ & $\begin{array}{l}\text { Total Number } \\
\text { On } 2005\end{array}$ & Note \\
\hline & & & Establish Local Television Association \\
\hline Local Television & Not available & 20 & Indonesian (ATVLI) \\
\hline Cyber Media & 3 & 5 & $\begin{array}{l}\text { Until now there is no association for } \\
\text { news media. }\end{array}$ \\
\hline
\end{tabular}

In the above table mentioned from the data 279 mass media until 2005 jumped to 600 mass media. While the television station from 5 to 10 media TV incorporated in the container ATVSI (Association of Private Television Indonesia). And the number of radios in 2005 from tiak is known to be 831 radio stations. Then for the local TV media amounted to 20 and cyber media from 3 to 5 media. Of course the current number will continue to grow again.

The current media industry liberalization has grown at an amazing rate, but not all of them can survive. In the media industry, survival is determined by the context of political economy. This reflects a global trend, ie only a small number of media companies actually own and control the development of the media industry (including access to media) and have power over the distribution of content to other parts of the world (Gabel and Bruner, 2003).

The writing of this article will address three important aspects in tracking the role and regulation of media policy development in Indonesia, as well as analyzing and considering all empirical data available in both primary and 
secondary data using a qualitative approach. That is the methodology approach based on the subjectivity and knowledge and experience of the author.

At a micro level, it can map a number of grassroots responses to media policy, particularly with regard to initiatives in generating and distributing content, as well as impacts that arise in the local (or perhaps more extensive) socioeconomic and political context. So from the two objectives above, the author will reveal some points, namely: First, the definition of 'civil society groups' does not necessarily mean NGOs or formal civil groups. Civil society groups here may mean privately or independently organized interest groups, which usually have no direct relationship with government agencies or private firms; personally, both formally and informally, organize the group to achieve certain goals or values (Nugroho, 2007, 2008, 2010b; 2011b; 2011c; Nugroho and Tampubolon, 2008).

Second, in the analysis of writing trying to use the perspective of citizens' rights to the media. This is in response to most of the data and information about the media referring to the use of Article 19 of the Universal Declaration of Human Rights (UDHR) 1 in order to defend media rights (in this case particularly the freedom of the institution or the press). In this case more is needed to protect citizens who have limited freedom in the media.

From the above statement, the citizens' rights to the media in three dimensions according to FI, FNS, (2010), states: First, the right of citizens in obtaining information, with a primary focus on the right to access reliable information and access to information. Reliable information will help citizens make the right decisions in their lives or to take part in decision-making processes related to citizenship. Access to information makes it possible for citizens to create content that can empower themselves. Typically, self-generated content from the bottom (bottom-up) will produce more reliable information.

The location of this research is limited only to the media in Indonesia that is considered to know by the author in order to facilitate the author in describing the existing media problems today. While the frame of thought of article writing is composed of several elements. First, look at the practical importance aspect of the research by defining the policy, mutatis mutandis (important changes have been made), in terms of the extent to which the policy aims to impact. Includes a loose view of policy: "something greater than a special decision, but smaller than general social movement" (Heclo, 1972, quoted in Parsons, 1995: 13).

The results of writing with major approaches in research and media analysis are often reduced and fail to recognize the natural characteristics of the mass media as the public sphere and the complexity behind the mass media performance. This should be fixed. Otherwise, the risk is that there may be three important aspects of media research that have escaped attention: (a) To what extent and how media policies relate to the expansion of the mass media industry 
today; (b) To what extent and how media policies affect the content of the mass media; (c) Are current media policies and regulatory frameworks sufficient to ensure the willingness of the mass media to civilize the public, and if so, to what extent does it affect.

From the problems described above, then the formulation of the problems posed by the authors is the Analysis of Government Regulation Policy Against Media in Indonesia? So to answer the problems mentioned by the author above, the authors will describe four points, namely: 1. Literature Review, consisting of Media Policy during the New Order, Media Mapping Media Indonesia, consists of, 2. Discussion and Clussion.

\section{Literature Review}

\section{Media Policy during the New Order}

Research writing out some of the previous researches: First, Hill and Sen's (2000) research on media in Indonesia (Media, Culture and Politics in Indonesia by David T. Hill and Krishna Sen is probably the most cited, because this study included the dynamics of the press, mainstream media, and popular culture in Indonesia during the New Order.Not many studies have succeeded in understanding the national media because it is related to the existence of a regime that opposes various forms of press freedom.In doing so, The New Order is "difficult." Secondly, in Do not Shoot the Messenger (Piper, 2009), Tessa Piper reports the policy challenges facing the media in Indonesia, outlining important facts about the latest developments in press freedom and freedom expression in Indonesia. Public policy plays an important role in creating an atmosphere that "jostles" journalists, information activists, and the public in general, which cuts the desire to practice the freedom to create and share information (Piper, 2009).

In the same topic, Mendel, (2010) funded by the Open Society Foundation, wrote Audiovisual Media Policy, Regulations and Independence in Southeast Asia (2010). It provides a view of media policy, particularly broadcasting regulations, in Southeast Asian countries, and links it with the character of government and / or regime respectively. So media policy is an important indicator of the overall democratic process in Southeast Asia. As well as trying to assess the extent to which new media can serve as an alternative to traditional broadcasting (Mandel, 2010).

Freedom Institute and FNS launched a study entitled Ensuring the Law and Civil Rights: Press, Film and Publishing (2010). This joint study is an example of research that uses the perspective of citizens' rights in observing the latest media and press developments in Indonesia (Freedom House, 2011). In particular, this study discusses citizens' rights within the scope of press, film 
and literature. In relation to policy, a number of key findings that support the analytical framework of our research are: (i) that there are overlapping policies and regulations that can be interpreted unilaterally to support policy makers' interests.

\section{Media Policy Mapping in Indonesian}

Mass media and media technologies have impacted individuals and communities globally on a greater level than ever imagined (Thompson, 1995). The effects that arise include the diverse experiences of all human beings, including affection, awareness, and behavior in community activities, events, and interactions (McLuhan, 1964).

As important as the role of mass media in mobilizing change in society, media must be regulated to ensure the achievement of improvement in social life (Habermas, 1984). Because the media is essentially a public case and the scope of its work is always in the public sphere (Herman and Chomsky, 1988). However, managing the mass media in Indonesia through policy is a hard idea, even almost impossible.

The mass media could be a sector where such contradictions are most clearly visible and have a detrimental effect on many people. However, this has been ignored, for example Broadcasting Act no. 32/2002 which seeks to promote the diversity of content and ownership of the mass media. Other regulations such as Government Regulation no. 49-52 / 2005 which should support the Broadcasting Act, undermines these values by allowing companies or media groups to operate up to cover 75 percent of the total province in Indonesia. This regulation continues despite the DPR has questioned it (KPI, 2006).

Analyzing the dynamics of media policy in Indonesia, in an effort to understand how policies over time in Indonesia try to guarantee and protect the public character that should be attached to the mass media, this task is not easy. Because analyzing media policy requires not only the knowledge and understanding in uncovering the processes of policy-making sumir (KPI, 2008).

There are two important aspects that the author will explain, namely: First, research writing is expected to open and scrutinize the public character of the media, especially those related to media alignments to the public which until now only an assumption and tends to be underestimated. This kind of precision is important, as it makes the public able to become more critical of the consequences of mass media practice in Indonesia, whether intentional or otherwise (Schultz, 1998: 49).

Secondly, the writing of this research is expected to provide confirmation space on two important aspects, namely the importance of the 
mass media as the 'Fourth Pillar' (Carlyle, 1840: 392;) that plays a vital role in efforts to mature society in the midst of modernization and globalization current media experienced Liberalization in the flow of young democracy. And how the various problems and contradictions of the media give space to the political agenda that led to the decline of social function of the mass media itself.

\section{Policy Analysis of Media Regulation in Indonesia}

Policy analysis, Parsons (1995) states that policy "is an approach to public policy aimed at uniting and contextualizing a number of models and research from that discipline, which is problem-oriented and policy-oriented" (pp. Xv). In addition, mention levels or levels of analysis that distinguish three levels, namely: meta, meso, and micro (Parsons, 1995). That is in addition to the three paradigms in public policy making and analysis (incrementalist, rationalist, and strategic). Meta analysis is the highest level that 'analyzes the analysis' itself. In empirical work, this is usually done after the primary analysis is done, to evaluate the analysis critically by assessing its assumptions, origins, and importance (Parsons, 1995). Meso analysis focuses on defining the problem, how the agenda (which will be handled by the policy) is defined, and how the policy is formulated (Parsons, 1995: 85). This will help us frame the case as it focuses on the issue, and get an analysis aimed at "improving the quality of the policy" (Hill, 1999: 2). This level of analysis is helpful for assessing specific policies of a country or sector, as in this case: media policy in Indonesia (see also John, 1998).

Media is a contested realm, parties who are able to gain sufficient power in influencing the policy-making process can also determine the content of the policy in question, according to their interests. This is where the group and network approach (Parsons, 1995) and the evolutionary perspective (John, 1998) can provide a specific framework for understanding the policy-making process. Nevertheless, the authors eventually made the writing generally accessible to the wider community, especially for various civil society groups. In accordance with Mundy and Sultan (2001), as quoted in Zanello (2009: 7), "information is only useful if available, if users have access to that information, available in appropriate form and language" (p. 7). In doing so, we hope that this research can have an impact by making it available to civil society groups to allow for the emergence of civil society-driven change (Berkhout et al., 2011). This is the reason why writing is straightforward, and practical, and friendly. So it can be useful for every citizen who can and can access it quickly and affordable (Zanello, 2009). 


\section{Discussion and Conclusion}

\section{Discussion}

Historically, the 1998 Reformation was a turning point and was seen as the main foundation in ensuring citizens' rights to the media. After that, the amendment of the 1945 Constitution and Human Rights Law no. 39/1999 which guarantees the right to information and media to citizens. The two postreform policies have become the legal and regulatory framework of the media, namely the Press Law no. 40/1999 and Broadcasting Act no. 32/2002. Normatively both rules are on the right track, guaranteeing basic prerequisites for citizens to exercise freedom of expression and opinion. Even so, the implementation has a different story.

Media regulation policy in Indonesia is almost less successful as an industry. The existing policy is incapable of regulating the profit-oriented economic principles applied by the media. Meanwhile, policymakers and governments fail to regulate the strict limitations of practice between monopoly and oligopoly. The absence of a policy that specifically considers the commercial aspects of the media industry and regulates its activities is one of the factors enabling rapid industrial expansion. Although the Broadcasting Act no. 32/2002 has contained several restrictions (Article 18) and prohibited cross ownership, but Government Regulation no. 50/2005 failed to support the policy.

Most of the impacts and accessibility of citizens to media are influenced by policies governing non-media matters. For example, the Information and Information Technology Act (ITE) no. 11/2008, Pornography Act no. 44/2008, and the Criminal Code (Penal Code). These policies are usually based on thoughts of public morality and contain unclear definitions of rules. Therefore, society and media workers are always at risk of being criminalized and accused of defamation. The use of rubber articles is also the easiest way to silence public opinion. Public opinion is not only hampered by a number of policies, but also by the media agenda itself. Internal censorship and the interests of media owners emerged as a way of setting real agenda and could threaten the existence of an open public sphere. Implementation of a networked broadcast system remains a major factor in democratizing the broadcasting system. That way, revising the Broadcasting Act will be an important test for all concerned parties.

In connection with the failure of the application of networked broadcasting systems, private broadcasting has dominated the broadcasting world and is the first, and even the only, choice in television media. In an ideal situation, public broadcasting (TVRI and RRI) will manifest its role in 
providing content that is neutral and ad-free. So it can provide an alternative for the public.

Despite being decisive in the effort to educate the public through the media, the regulators are weak in managing the media. The main institutions involved are the Indonesian Broadcasting Commission (KPI), the Press Council, the Indonesian Telecommunication Regulatory Body (BRTI), the Business Competition Supervisory Commission (KPPU), and the Ministry of Communications and Informatics (Kemenkominfo). Current conditions have reached less institutional success levels. Because the media industry has been able to beat the regulations or regulations made by the regulators.

Media policy is reactive to the changes created by technological innovation in society. Convergence and digitization will be the next test. Recent technological developments are very promising, even going to change the use of media. Digitalization will provide many opportunities by opening new channels. This will create new opportunities for the media to contribute to providing a variety of content.

\section{Conclusion}

The author sees from the development of Indonesian media currently concludes as follows: the development of policy analysis of the role of media in Indonesia needs to be improved in terms of regulation, and alignment over the control of its citizens. As the progress and decline of media development in Indonesia will be highly dependent on regulators who make the rules while maintaining the rights of their citizens as a medium of control over the existence and alignment of the media as the public interest. Although the media themselves are actually very open to active public engagement, only in the fact that the role of citizens of the rights of control and regulators of rulemaking is outweighed by interest groups who have been in control of the content and the media industry itself. Therefore, it needs serious struggle to improve the condition of media development in a policy that is in favor of the public interest.

\section{References}

AJI, 2009. The face of Media Cracking. Jakarta: AJI and Tifa Foundation.

Balabanova, E., 2010. Media Power During Humanitarian Interventions: Is Eastern Europe Any Different from the West? Journal of Peace Research January 201047 (1), 1 71-82.

Berkhout, R., Koster, K.d., Kieboom, M., Pieper, I., Fernando, U., Ruijmschoot, L., 2011. Civic Driven Change: Synthesising Implications for Policy and Practice. Report. Development Policy Review Network. 
BPS, 2011. Statistics Communication and Information Technology in Indonesia. Jakarta: Central Bureau of Statistics.

Carlyle, T., 1840. Lecture V: The Hero as the Man of Letters. Johnson, Rousseau, Burns. James Fraser [Reported with emendations and additions (Dent, 1908 ed.)], London.

Coyne, C.J., Leeson, P., 2009. Media, Development and Institutional Change. Edward Elgar, Cheltenham, UK.

Press Council, 2011. The draft of Siber Media Coverage Guidelines. Board of Press Indonesia, http: // dewanpers.or.id/kegiatan/berita/885-rancanganpedoman-pemberitaan-media-siber, viewed 08 February 2012.

FI, FNS, 2010. Upholding the Laws and Rights of Citizens: Press, Film, and Publishing. Final report. Jakarta: Freedom Institute and Friedrich Naumann Stiftung.

Freedom House, 2011. Freedom on the Net. Report. Washington DC: Freedom House.

Gabel, M., Bruner, H., 2003. Global, Inc. An Atlas of the Multinational Corporation. The New Press, New York.

Habermas, J., 1984. The Theory of Communicative Action. Vol. I: Reason and the Rationalization of Society. Beacon. [German, 1981, vol. 1], Boston.

Herman, E.S., Chomsky, N., 1988. Manufacturing Consent: The Political Economy of Mass Media.Pantheon Books New York.

Hill, D.T., Sen, K., 2000. Media, Culture and Politics in Indonesia. Oxford University Press, Oxford.

John, P., 1998. Analysing Public Policy. Continuum, London.

KPI, 2006. Chronology of Controversy Government Regulation on Broadcasting. KPI, http://www.kpi.go.id/ index.php? Option = com_content $\&$ view $=$ article \& id $=129 \%$ 3Achronology + Controversy + Regulation $\mathrm{n}+$ Government + about + Broadcasting $\&$ catid $=14 \% 3 \mathrm{~A}$ in-countrygeneral \& lang = id, viewed 08 February 2012.

KPI, 2008. Year End Report .. Jakarta: Indonesian Broadcasting Commission.

Laksmi, S., Haryanto, I., 2007. Indonesia: Alternative Media Enjoying a Fresh Breeze, in: Seneviratne, K. (Ed.), Media Pluralism in Asia: The Role and Impact of Alternative Media. Asian Media and Information Center, pp.

McLuhan, M., 1964. Understanding Media: The Extensions of Man. McGrawHill, New York.

Mendel, T., 2010. Audiovisual Media Policy, Regulation and Independence in Southeast Asia. Report. Washington DC: Open Society Foundations.

Mundy, P., Sultan, J., 2001. Information Revolutions: How Information and Communication Management is Changing the Lives of Rural People. Sayce Publishing, London.

Nugroho, Y., 2007. Does the Internet Transform Civil Society? The Case of Civil Society Organizations in Indonesia. PhD. thesis. Manchester: The University of Manchester.

Nugroho, Y., 2008. Adopting Technology, Transforming Society: The Internet and the Reshaping of Civil Society Activism in Indonesia. International Journal of Emerging Technologies and Society 6 (22), 77-105. 
Nugroho, Y., 2010a. Localising the Global, Globalizing the Local: The Role of the Internet in Shaping Globalization Discourse in Indonesian NGOs. Journal of International Development DOI.10.1002 / jid.1733.

Nugroho, Y., 2010b. NGOs, The Internet and sustainable development: The case of Indonesia. Information, Communication and Society 13 (1), 88-120.

Nugroho, Y., 2011a. Citizens in @ction: Collaboration, participatory democracy and freedom of information - Mapping contemporary civic activism and the use of new social media in Indonesia. Report. Manchester and Jakarta: MIOIR and HIVOS.

Nugroho, Y., 2011b. Citizens in @ction: Collaboration, participatory democracy and freedom of information. Mapping contemporary civic activism and the use of new social media in Indonesia. Report. Manchester and Jakarta: HIVOS Southeast Regional Office and University of Manchester's Institute of Innovation Research

Nugroho, Y., 2011c. Opening the black box The adoption of innovations in the voluntary sector - The case of Indonesian civil society organizations. Research Policy 40 (5), 761-777.

Nugroho, Y., Tampubolon, G., 2008. Network Dynamics in the Transition to Democracy: Mapping the Global Networks of Contemporary Indonesian Civil Society. Sociological Research Online 13 (5).

Parsons, W., 1995. Public Policy: Introduction to the Theory and Practice of Policy Analysis. Edward Elgar, Cheltenham.

Piper, T., 2009. Do not shoot the messenger: Policy challenges facing the media. Report. Thornley, A.

Schultz, J., 1998. Reviving the fourth estate. Cambridge University Press, Cambridge, England.

Thompson, J.B., 1995. The Media and Modernity; A Social Theory of The Media. Polity Press, Oxford.

Zanello, G., 2009. Strengthening citizen agency through ICT: An extrapolation for Eastern Africa. Public Management Review 13 (3), 363-382. 